\title{
Psychotic Episode Induced by St. John's Wort (Hypericum Perforatum): A Case Report
}

\author{
Mehmet Gurkan Gurok¹, Osman Mermi², Faruk Kilic², Fatih Canan³, Murat Kuloglu³
}

\section{ÖZET:}

Sarı kantaronun (Hypericum perforatum) neden oldug̃u psikotik atak: Olgu sunumu

Son yıllarda dog̃al ürünlere ilginin giderek artması ile bitkisel tedavilerin kullanımı tüm dünyada giderek yaygınlaşmaktadır. Bitkisel tedaviler içerisinde psikiyatrik bozuklukların tedavisi amacıyla sıklıkla kullanılanlar arasında, sarı kantaron olarak da bilinen Hypericum perforatum da yer almaktadır. Sarı kantaron, bașta hafif ve orta șiddetteki depresyon olmak üzere, uykusuzluk ve kaygı gibi belirtilerin tedavisinde kullanılmaktadır. Etki mekanizması tam olarak aydınlatılmamış olmasına rag̃men aktif bileșenlerinin antidepresan etkiye sahip oldug̃u düșünülmektedir. Yazımızda, 47 yașında, daha önce psikoz öyküsü olmayan ve sarı kantaron kullanımı sonrası psikotik hecme geçirdikten sonra antipsikotikle bașarılı șeklide tedavi edilen bir kadın hasta sunulmuștur.

Anahtar sözcükler: sarı kantaron, psikotik atak, bitkisel tedavi

Journal of Mood Disorders 2014;4(1):38-40

\section{ABSTRACT:}

Psychotic episode induced by St. John's wort (Hypericum perforatum): a case report

There is an increase in the use of herbal therapies in recent years. St. John's Wort (SJW), which is also named as Hypericum perforatum, is one of the most frequently used herbal agents in the treatment of psychiatric disorders. SJW has been shown to be efficacious in treating mild to moderate depression, insomnia, and anxiety disorders. Although exact mechanism of action is not completely understood, its active components are suggested to have antidepressant properties. Despite its beneficial therapeutic effects, SJW can also cause unexpected adverse effects. Herein, we present the case of a 47-yearold, previously healthy female who developed psychosis after taking SJW extract and successfully treated with antipsychotic therapy.

Key words: herbal therapy, psychosis, St. John's wort

Journal of Mood Disorders 2014;4(1):38-40

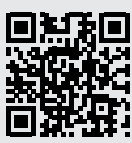

'Elazı̃̃ Mental Health Hospital, Elazı̃̃-Turkey 2Firat University School of Medicine, Department of Psychiatry, Elazı̃̃-Turke ${ }^{3}$ Akdeniz University School of Medicine,
Department of Psychiatry, Antalya-Turkey

Yazıșma Adresi / Address reprint requests to: Fatih Canan, MD

Fepting school of Medicine, 07059, Kampüs, Antalya-Turkey

Telefon / Phone: +90-242-227-4400

Faks / Fax: +90-242-227-5540

Elektronik posta adresi / E-mail address: faithcanan@gmail.com

Kabul tarihi / Date of acceptance: 30 Aralık 2013 / December 30, 2013

Bag̃ıntı beyanı:

M.G.G., O.M., F.K., F.C., M.K.: Yazarlar bu makale ile ilgili olarak herhangi bir cıkar çatışması bildirmemişlerdir.

Declaration of interest: M.G.G., O.M., F.K., F.C., M.K.: The authors reported no conflict of interest related to this article.

\section{INTRODUCTION}

In recent years, herbal therapies are gaining popularity as alternatives to prescribed drugs. The use of medicinal plants in treating medical diseases is a part of complementary medicine and named as phytotherapy (1). The patients with a psychiatric disorder use complementary approaches more frequently than the general population (2).

The World Health Organization (WHO) defines herbal medicine as herbal products that contain as active ingredients parts of plants, or plant materials, or combinations thereof (3). Herbal agents are used in the treatment of psychiatric disorders such as depressive disorders, somatoform disorders, anxiety disorders, sleep disorders, and psychotic disorders (1).

St. John's Wort (SJW), which is also named as Hypericum perforatum, is one of the most frequently used herbal remedies for the treatment of psychiatric disorders. Other herbal agents used in the treatment of psychiatric conditions include Melissa officinalis (lemon balm), Ginkgo biloba, Ginseng, Passiflora incarnata, Piper methysticum (Kava-Kava), and Valeriana officinalis (Valerian) (1).

SJW has been shown to be efficacious in treating mild to moderate depression, insomnia, and anxiety disorders (4). SJW, which is extracted from the naturally occurring plant Hypericum perforatum, is found in almost all regions of the world $(1,4)$. It has many active components including hyperforin, flouroglucinol, flavonoids, 
quercetin, hyperoside naftodiantrons, hypericin, pseudohypericin, kaempferol, and luteolin. Although exact mechanism of action is not yet known, active components such as hypericin, hyperforin and, flavonoids are suggested to exhibit antidepressant properties (4).

In this paper, we present a case of a 47-year-old, previously healthy female who developed a psychotic episode after taking SJW extract. We aim to renew awareness of unreported herbal medicine use and its effects on diagnosis and management of patients presenting with psychotic symptoms.

\section{CASE REPORT}

M.E. is a 47-year-old female housekeeper with three children. She was admitted to psychiatry outpatient clinic following a one-week period of smiling or laughing without obvious reason, disorganized speech, bizarre behavior, persecutory delusions, visual and auditory hallucinations, social/emotional withdrawal, and selfneglect. Her husband reported a gradual decline in her mental state, starting with ideas of being followed by someone. She had been previously well, with no medical or psychiatric history. On mental state examination, the patient was co-operative but anxious and reported visual/auditory hallucinations, insomnia and delusions of reference. She denied any changes in appetite and libido. Her family history was positive for anxiety disorder in a first-degree relative. The patient did not report using any prescribed drugs in the past six months. However, she had been drinking three glasses $(600 \mathrm{ml})$ of SJW extract daily for seven days, because of difficulty falling asleep. Her physical and neurological examinations were unremarkable. Electroencephalogram (EEG) and cranial magnetic resonance imaging (MRI) were normal. Laboratory tests including complete blood count, biochemical and endocrinological parameters were in normal range. The symptoms were interpreted as a psychotic episode, possibly associated with SJW. Therefore, SJW was stopped and intramuscular haloperidol, $10 \mathrm{mg} /$ day, was started. By the $7^{\text {th }}$ day of the treatment, a significant improvement in her symptoms was observed and intramuscular haloperidol was changed to oral olanzapine, $5 \mathrm{mg} /$ day. The 3-month follow-up of the patient revealed no psychotic symptoms.

\section{DISCUSSION}

With the increasing interest in alternative therapies, individuals, especially those with psychiatric disorders, frequently use herbal medicines. Despite the belief that these agents are 'harmless', they can cause adverse effects related to several organ systems. It is generally believed that herbal medicine related side effects are infrequent complications that are easily manageable (1). However, there is a significant amount of literature showing that herbal therapies may lead to severe conditions such as serotonin syndrome, psychotic disorder, panic attack, and manic episode (5).

SJW has a proven efficiency in the treatment of mild to moderate depression (6). There are also studies that show beneficial effects of SJW on premenstrual syndrome and anxiety disorders $(2,7)$. Short-term use of SJW has been reported to be well tolerated with a minimal adverse effect profile. However, there is limited data about the long-term use of SJW, particularly in high doses (8). The most frequently reported side effects of SJW are gastrointestinal symptoms, photosensitivity, sedation, headache, increased anticholinergic activity, and dermatologic symptoms. SJW is not recommended in patients with pheochromocytoma, cardiovascular disease, pregnancy, or lactation (5). Moreover, SJW can alter blood levels of a variety of drugs via inducing cytochrome 3A4 activity. In most of the case studies about SJW-associated serotonin syndrome, concomitant use of selective serotonin reuptake inhibitors, tricyclic antidepressants, or venlafaxine was reported as well (8). Combining SJW treatment with antidepressants is not recommended (9).

There are several case reports describing manic episode during use of SJW $(5,10)$. SJW has also been shown to aggravate psychotic symptoms in patients with schizophrenia (11). However, we believe, there is only one report demonstrating SJW-related psychotic symptoms in an individual without a history of psychosis (12). In that case report, Shimuzi et al.(12) have stated that their patients' psychotic symptoms did not resolve on followup. Thus, the authors concluded that the diagnosis of the patient was schizophreniform disorder according to DSMIV-TR. The psychotic symptoms of our patient have completely resolved and she remained psychiatrically stable without any residual symptoms during 3-month 
follow-up. In addition, the timing of onset of psychosis is usually in adolescence or young adulthood, but our patient was 47-years-old. Her physical and neurological status was normal, as well as laboratory and imaging results. Thus, she was diagnosed as having SJW-induced psychosis.

It has not been clearly understood how SJW induces mania or psychosis. The active components of SJW act as nonspecific inhibitors of serotonin, noradrenaline, and dopamine (13). In animal models, SJW was shown to increase extracellular dopamine levels in prefrontal cortex (14). It can also affect the functioning of GABA, glutamate, and NMDA receptors (13). These complex effects of SJW may cause or trigger psychotic symptoms in vulnerable individuals.

\section{References:}

1. Bruhn JG. The use of natural products in modern medicine [phytotherapy]. Acta Pharmaceutica Nordica. 1989;1:117-30.

2. Unutzer J, Klap R, Sturm R, Young AS, Marmon T, Shatkin J, Wells $\mathrm{KB}$. Mental disorders and the use of alternative medicine results from national survey. Am J Psychiatry. 2000;157:1851-7.

3. World Health Organization (WHO). National policy on traditional medicine and regulation of herbal medicines Report of a WHO global survey; 2005.

4. Dhingra S, Parle M. Herbal remedies and nutritional supplements in the treatment of depression: a review. BCP. 2012;22:286-92.

5. Hammerness P, Basch E, Ulbricht C, Barrette EP, Foppa I, Basch S, Bent S, Boon H, Ernst E; Natural Standard Research Collaboration. St John's wort: a systematic review of adverse effects and drug interactionsfor the consultation psychiatrist. Psychosomatics. 2003;44:271-82.

6. Clement K, Covertson CR, Johnson MJ, Dearing K. St. John's wort and the treatment of mild to moderate depression: a systematic review. Holist Nurs Pract. 2006;20:197-203.

7. Stevinson C, Ernst E. A pilot study of Hypericum perforatum for the treatment of premenstrual syndrome. BJOG. 2000;107:870-6.
In conclusion, this case demonstrates that sudden onset of psychotic disturbances in the absence of other known organic factors could be related to treatment with SJW in individuals without a history of psychosis. Also, this case shows that treatment with antipsychotics can be highly effective in SJW-associated psychosis. Patients generally are not likely to report having used alternative medicines. It is important, therefore, that physicians elicit information about herbal remedy use in patients presenting with psychiatric complaints. The use of herbal therapies should be considered and questioned in patients with first-onset psychosis or confusion. The relationship between SJW use and psychosis needs to be clarified in future studies.

8. Schulz V. Safety of St. John's wort extract compared to synthetic antidepressants. Phytomedicine. 2006;13:199-204.

9. Zhou S, Chan E, Pan SQ, Huang M, Lee EJ. Pharmacokinetic interactions of drugs with St John's wort. J Psychopharmacol. 2004;18:262-76.

10. Güzelcan Y, Scholte WF, Assies J, Becker HE. Mania during the use of a combination preparation with St. John's wort (Hypericum perforatum).Ned Tijdschr Geneeskd. 2001;145:1943-15.

11. Lal S, Iskandar H. St. John's wort and schizophrenia. CMAJ. 2000;163:262-3.

12. Shimizu K, Nakamura M, Isse K, Nathan PJ. First episode psychosis after taking an extract of Hypericum perforatum (St. John's wort). Hum Psychopharmacol. 2004;19:275-76.

13. Butterweck V. Mechanism of action of St John's wort in depression: what is known? CNS Drugs. 2003;17:539-62.

14. Yoshitake T, Iizuka R, Yoshitake S, Weikop P, Müller WE, Ogren SO, Kehr J. Hypericum perforatum L (St John's wort) preferentially increases extracellular dopamine levels in the rat prefrontal cortex. Br J Pharmacol. 2004;142:414-8. 